\title{
Globalised mission as opportunity
}

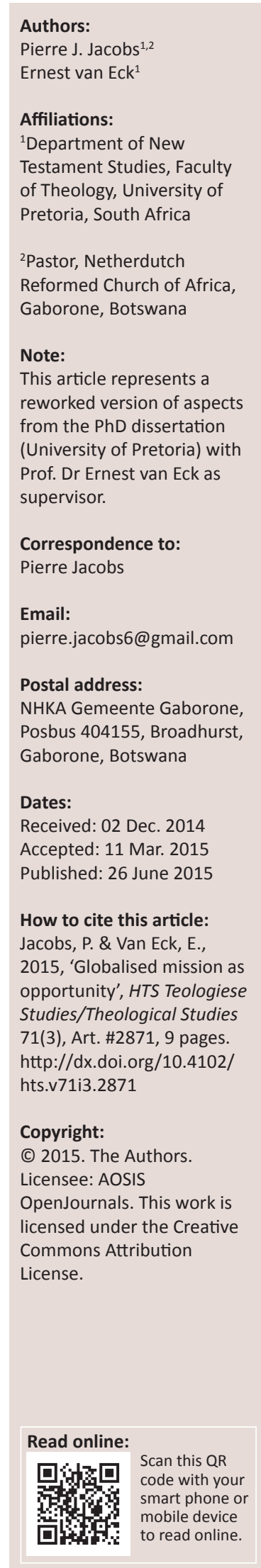

Globalisation develops at a staggering pace that envelopes and infiltrates local South African communities in various ways. Through technology a person can have access to anything today. Should the church try to keep up, or compete with such a reality? This article aims to encourage the church to develop a responsible missional character, which embraces the opportunities globalisation offers - to be a participative forum in a community comprising of more than religious people. Through re-evaluating the church's missional intent, by shifting the paradigm away from self-centred outcomes, the church should contribute to such a community's articulation of faith.

\section{Introduction}

The third millennium's intersection of globalisation, mission and secularisation initiates a dialogue in the Netherdutch Reformed Church of Africa (NHKA) ${ }^{1}$ that confronts its own objectives on the outcomes and motives of its understanding of being missional ${ }^{2}$ in its immediate community. An immediate community comprises the neighbourhood around a church and not only its members in various locations around town. Globalisation's impact on the NHKA's missional identity is significant because of a shortfall of continuous development of the church's identity ${ }^{3}$ in South Africa, especially with regard to mission and evangelisation (see NHKA 2007:62-63; 2010:229). For the church to be proficient in its missional development the multidimensional influence of globalisation, the radical (read 'essential') implication of missio Dei, and the contextual realities of secular communities should be rediscovered. The focus should not be on redefining contextual theology for the church in South Africa, a term Stephan Bevans (2002:80) argues has replaced the term 'indigenous theology'. This study departs form Angie Pears's (2010:178) interpretation of contextual theology as used by liberation theologies that 'call for reflective and responsive theologies which articulate the contextual factors that motivate them.' For Pears (2010:1) the term contextual theology refers 'to Christian theology, which is explicitly shaped, if not driven, by the recognition of the contextual nature of theology with all of its potentially controversial and problematic implications'.

This understanding differs from the claim that all theology is contextual. Pears (2010) explains that:

$[O]$ ne is a theological stance which places and celebrates context at the center of the theological enterprise, and the other an epistemological claim about the contextual nature of all theology. (p. 1)

A relevant foundation for a missional character could be identified in Jesus' significant representations of the kingdom of God that are utilisable for the church in South Africa, even today. Contemporary secularists ${ }^{4}$ might not commend the church with the custody of such a fundamental burden of responsibility. Yet, considering the tumultuous times ${ }^{5}$ we live in, a structure of sustainable values for missional action are important.

The church's self-bequeathed charge to further - for example through mission - their essential beliefs, are threatened when globalisation tolerates uncontrolled transformation worldwide. The tension between (established) church and (bequeathed) charge are, ironically, nullified

1.The Netherdutch Reformed Church of Africa (NHKA) serves as reference to "church' in this article, except where indicated otherwise.

2.This article understands the term 'mission or missional' in the sense of David Bosch's (2001:512) understanding, namely that mission is multidimensional and covers a broad spectrum, including 'witness, service, justice, healing, reconciliation, liberation, peace, evangelism, fellowship, church planting, contextualization, and much more.' Also see Van der Merwe (2011:6 of 9) for a definition of 'missional theology'.

3.Van Wyk, I. (2013:1 of 9) shows that the 'NHKA is growing smaller' (see also Ungerer 2013; Van Wyk, D. 2013; Van Wyk, W. 2013).

4.This study draws from Charles Taylor's understandings of 'secular' in Smith (2014:20).

5.Consider on a global level, for example, the Islamic State of Iraq and ash-Sham (ISIS) that utilises extremist ideologies with a religious foundation that spreads fear and destruction. On a local level, the South African governments' decisions have an impact on the masses of low and middle income communities. 
through (counterproductive) self-preservation of the church. Therefore the need for a re-evaluation of the church's missional character is necessary; a re-evaluation that will be concrete enough to sustain its Christian ethos while being able to adapt and improvise to whatever obstacle (globalisation) presents itself in contemporary South Africa. The church's task is to react to its current crisis with informed and sustainable solutions that have to resonate with the church's immediate context, and stay collaborative with scriptural truths as regulatory parameters.

In this article the intersection of the themes globalisation, missio Dei, and participation in community challenge the 'local church to rethink being church in the world through an alternative hermeneutical reading of the Bible and the context it was written in' (Niemandt 2012:8).

\section{Globalisation}

'Globalization ${ }^{6}$ is a force, it is here, and it is driven by people, and it has good and bad effects' (Blair 2009). Globalisation is multidimensional, including facets such as economics, politics, cultural phenomena, and religion.

Globalisation is not, as sometimes negatively viewed, ${ }^{7}$ the global integration of processes or systems, but a complex density of processes and systems: ${ }^{8}$

It is not only an economic phenomenon and its impact is not only economic. It is a much broader, deeper, and more complex phenomenon, involving new forms of communication and innovation. (Friedman 2007:482)

Robertson (2000:54) argues that this interdependence 'is not the same as integration, and that the simultaneously cultural, economic and political global processes of globalization, is [sic] not reduced to mere economistic unification.' Thus, the integration and diversity of cultures, economies, interterritorial boundaries and the global shift of interdependence, requires not a mere acceptance of globalisation, but a means of reacting to it. This confronts the church head on with the challenge to be a dependable voice for the immediate community influenced by globalisation. Schreiter (2007:116) is insistent that 'local theology is bound to Christian tradition by its use of and relationship to Christian scripture.' It would be surprising, writing from a Christian perspective, to suppose that the South African context, globalising at this pace, can be formed without a particular foundation of religious self-understanding. As a church established among the globalising people of South Africa, we need 'a compelling

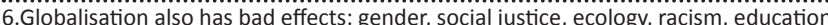
migration, diaspora communities, poverty and wealth disparities, while growth issues relate to new cultural trends, ministerial formation, theological education, missionary structures and strategies.

7.This is true of Christian voices as well as analysts indifferent to Christianity. See for example, Litonjua (1999:210) and Hellyer (1999). Hellyer lists the best available bibliography relating to attacks on globalisation, understood as the increasing influence of the World Bank, the International Monetary Fund (IMF), and all who cooperate with 'multinationals' and 'capitalism'.

8.See Held and McGrew (2000:6) for the argument that globalisation cannot merely be reduced to 'a purely economic or technological logic ... [which is] profoundly misleading since it ignores the inherent complexity of the forces that shape modern societies and world order.' theology on the one side, and a compelling ethic on the other, [which] are fateful for our civilizations' (Stackhouse 2000:25). Miroslav Volf (2008), in his Yale lectures Faith and globalisation argues the following:

[Globalization] is a planetary process which was historically primarily driven by trade, in learning about and spreading religion, interest in conquest, interest in adventure, in recent centuries, capitalism, a version of trade, a force that drives globalization. This leads to a world of high-level interconnectivity, communication, goods flow, but also interdependence.

This poses a paradox for religions. 'The different, but related, religions of the world existed side by side on a continuum of tolerance, indifference and ignorance' (Turner 2011:231). This is the paradox of globalisation; it 'compresses time and space by creating the world as a single place, but it also intensifies the problem of otherness' (Turner 2011:231). Kalu, Vethanayagamony and Chia (2010:33) classify two caveats in terms of globalisation and mission for the global Christian church. Firstly, globalisation cannot be blamed for every change (internal and external) in the global and local church today, but can be perceived as a catalyst. Secondly, the connection between Christian mission and globalisation is ironic because the missionary enterprise 'nursed the seed of globalisation' (Kalu et al. 2010:33). The worldwide development of globalisation expands over territorial boundaries and cultural identities. Globalisation's effect in the local context, for example in South Africa, creates the problem of otherness (Turner 2011:231). Globalisation creates the platform of opportunity, for example, for millennials ${ }^{9}$ to express their identity through the unlimited forum of the World Wide Web. This 'flat-world platform' enables them to express themselves from within their culture and becomes 'a very powerful force for the preservation and enhancement of cultural autonomy and particularity' (Friedman 2007:478). In effect, the traditional structures of authority imposed on communities become but one voice through which an individual can express her or himself.

Structures of authority guided the development, and acted as sets of powers, that were integral to societies. These sets of powers are family, economics, politics, cultures and religion. Three new global authorities emerged as 'techné, Gaia, and exemplars of new trans-ethnic, transcultural, transnational, trans-religious moral heroes' (Stackhouse 2001:31). Techné refers to uncontrollable technological development. Stackhouse (2001) identifies technological ${ }^{10}$ development as:

[A] practical adjustment to a fallen world, and has no positive significance for salvation, although it can have a negative meaning insofar as we come to love or trust unduly. (p. 26)

However, exaggerated confidence in technology could plunge the social world and us into non-being (Stackhouse 2001:26-27).

\footnotetext{
9.The Millennial Generation is generally categorised as born between 1980 and 1999 and Generation Z from 2000 to the present. See Millennial Impact Report 2014 for a summary given on 'Millennial generation' since 2009.

10.See also Hooykaas (1974) for older but substantially compatible accounts of these assumptions about technology.
} 
Gaia, refers to James Lovelock's theory of the earth named as 'a creature after the Greek earth goddess' (Lovelock 1987:10). To Moltmann the earth we live in works like a super-organism that functions as a whole, relating to earth as a whole in itself, and that is therefore alive (Moltmann 2001:181). The importance this hypothesis has for globalisation is that it helps the 'anthropocentric selfunderstanding and behavior of wo/men, and constrains them to fit democratically into the life of the earth as a whole' (Moltmann 2001:183). These new authorities are powerful and have a significant influence on traditional religious concepts of morality and secular theories of modernity. The question then arises for the church, as a relevant authority, whether it can develop its own character among various other influences of globalisation? Or will it disregard this potential of globalisation and lose more credibility to its immediate community?

A further theological reality, in terms of inter-religious development, is whether the Christian Messiah, Jesus 'is, can be, and should be, Lord over all the powers, principalities, authorities, and regencies in a global civilization'? (Stackhouse 2001:36). This is not an attempt to argue for a pluralistic understanding of faiths, neither is it an attempt to promote tolerance or an 'everything goes' culture.

Increasingly people have to think of themselves in terms of a multiplicity of identities ... gone are the days when one could define oneself in terms of a singular geographic space. In large part due to technologies, there has been a 'dissolution of oneself', a fragmenting of interests, values and affiliations such as that the individual has different identities that can vary as widely as the different interests, values and affiliations one might have. (Reader 2008:32)

Globalisation also 'creates homogeneity and a standardization of both place and culture, thus destroying real difference' (Reader 2008:26).

Volf (2008) says the 'whole planet itself becomes a locality. People on earth therefore become dis-embedded, de-moored, from particular places'; we encounter the development of 'dis-embedded cosmopolitans'. Tony Blair (2009) explains globalisation as a movement ${ }^{11}$ which:

Pushes people together, to live together, thrive together, regardless of place of birth. Therefore, the important factor is that we share the status of being human, not what typifies us in terms of gender, race, and ethnicity. People are losing identity. People feel threatened by the forces of globalization because the truths people grew up with are being challenged by other religions, or secular, to one's own.

Globalisation, as a force, draws people together. Friedman (2007:478-479) explains this phenomenon by saying the world is becoming flat, like pizza dough. Each community personalises their piece of dough. Bernard Stiegler, a

11.See Friedman (2007:478): 'Indeed, it is becoming clear that the flat-world platform while it has the potential to homogenize cultures, also has, I would argue, an even greater potential to nourish diversity to a degree that the world has never seen before.
French philosopher, says 'we need to reinvent an industrial society where culture returns to the heart of society' (Stiegler 2010). Stiegler encourages the 'individuising' of community members, and articulating of their own culture; a 'distributive culture' is a 'contributive culture' (Stiegler 2010). When the church understands this as an opportunity, and not opposition aimed at the NHKA as Christian church, then limitations set by church traditions should be rediscovered for the sake of an inclusive and just resolution for religious and secular communities alike. According to Stackhouse (2000):

This [globalization process] poses a critical, related question, namely whether the resources of civilization, now being generated worldwide, will differ from all of human history in that the emergent society will not have, or need, or desire a religious core, or a theological ethic to interpret, to repeatedly assess, and to guide it. (p. 25)

Such a core is needed. Herein is the opportunity for the development of a missional identity.

Contradictory to the idea of globalisation as being about the commodification and homogenisation of culture, Robertson (1992:172-173) stresses diversity as a basic aspect of the globalisation. Robertson evaluates globalisation in amoral terms, as neither inherently good nor bad, since sociological processes are framed by the accomplishments and failures of human agents. Robertson's emphasis on the reflexivity of global consciousness (our self-understanding as citizens of the world) implies that the process of globalisation has potential mechanisms for the development of cultural values capable of facilitating harmony and overcoming conflict (Robertson 1992:1-2).

Cultures are nested in environments, and the fact that more people can now not only survive but even thrive by staying home in their native region, in their own environment, has got to be a net plus for the forces of cultural diversity versus the forces of homogeneity. (Friedman 2007:479)

The democratic shift in South Africa over the last two decades can highlight the furtherance of human rights in recognising the equal dignity of women, the increasing emphasis on aid for the poor communities and other marginalised developments. However, the shift can be viewed as highlighting the dictatorship of relativism, the decline of religious practice of mainline South African churches, the seeming failure of family life and other signs of disintegration in contemporary culture. The cultural change in South Africa, and the globe, is much more subtle and complex than either of these positions allow. In both views of the cultural shift, positive and negative, elements are overlooked. For example, human rights are furthered, but in the same sense frightening to view marriage (and other significant relationships) as instrumental to meet individual needs.

What is needed is an analysis to account for the specific pockets of diverse cultures surrounding a church. The 
‘Declaration towards a Global Ethic'12 identifies two basic principles, on a global scale:

- No new global order can appear without a global ethic.

- The fundamental demand that every person must be treated humanely.

The local church must test its own notions of cultural homogeneity and particularity, associated with place, where contextual factors have an influence on authorities because of culture, history, and tradition. This does not mean any person should be characterised on their native context alone, which includes factors like nationality, ethnicity, race, and gender. Reader (2008:32) argues, with this discrepancy in mind, that neither does it appear to be the case that a 'sense of place continues to contribute to the creation of the self and indeed of social relationships in the same way as before.' Reader (2008) then asks:

Is it possible for the local church to be both a 'sticky place' and a 'slippery space', thus acknowledging the ambiguities and complexities of globalisation, and yet retaining a legitimate pastoral role and integrity in belief? (p. 118)

Friedman (2007:482) encourages the local culture to be exposed to the rich diversity globalisation offers:

Worrying about the pulverizing effects of globalization is very legitimate, indeed very important, but ignoring its ability also to empower individuals and enrich our cultural cornucopia misses its potentially positive effects on human freedom and diversity. (Friedman 2007:482)

This is the conundrum for the NHKA, and other South African churches, sharing in the reality of an accessible globalised diversity.

The prerogative for the church is to engage with a missional character that can converse with a globalised (local) world in a manner that recognises the social, political, cultural, economic and personal complexities of life for its local community in a trans-world space.

My point here is not that the flattening of the world will always enrich and preserve culture. My point is that it doesn't always destroy culture, which is the message you hear if you listen only to the globalization critics. The iron law of globalization is very simple: If you think it is all good or all bad, you don't get it. Globalization has empowering and disempowering, homogenizing and particularizing, democratizing and authoritarian tendencies all built into it. (Friedman 2007:482)

Globalisation's potential, illuminated through these ambiguities, confronts the NHKA's intent it has with mission, understood as a remedy to prevent a total schism between being a credible voice and an irrelevant institution (in the 21st century, at least).

12.The Global Ethic Foundation's, or Weltethos, website can be visited (viewed 15 May 2015). The Declaration also identifies four irrevocable directives: commitment to a culture of non-violence and respect for life; commitment to a culture of solidarity and a just economic order; commitment to a culture of tolerance and solidarity and a just economic order; commitment to a culture of tolerance and
life of truthfulness; and commitment to a culture of equal rights and partnership between women and men.

\section{Missional inquest}

Derived from the explanation above, it is evident that there exists a need for a sustainable missional character for the NHKA, and for this to happen it is important to uncover a concrete clarification of mission's essential imperative one that is too often misrepresented because the church misinterprets it. As Beyers (2013) argues:

The question as to the calling of the church is not a practical but a theological issue. The church can keep itself busy with activities that seem important for its own survival. Are these activities the motivation behind God's call to the church? (p. 1)

Beyers (2013:1) draws from Barth (1961), who shows how:

$[T]$ he church is always seen in relationship with God's intention with the community he assembles. This might be the true calling of the church: to be a community that calls others to community. (p. 205)

It is about mission through community, Beyers suggests, not through the church in particular. Van der Merwe (2011:8 of 9) is enthused by the church's realisation that it should undertake the process of rediscovering its culture. Van der Merwe (2011:8 of 9) further explains that the purpose of this process is to 'enable the church to make a paradigm shift with the aim of being a healthy and purposeful church in service of the missio Dei.'

Proposed purposeful projects (with questions) that the church could explore are:

- Poverty, suffering and marginalised communities: How do adjectives of Christian community such as 'discipling', 'healing', 'witnessing', and 'contextual' become lived realities in the church's mission?

- Globalisation and the imitation of imperialistic hierarchies: What is involved in being the church in the cities and megacities of today?

- Christianity and socio-political action: How can the local churches be agents of the kingdom of God and a source of healing and reconciliation?

- Identity, gender and power: What is the true identity (the 'core DNA') of the church? How does it manifest itself in different denominations and cultures?

- The interchange of migration, diaspora and ethnicity: What are the tensions between homogenous and multi-ethnic churches? How is church life in diaspora communities shaped?

- HIV and AIDS, church and mission: Does Christian mission bear a responsibility for the spread of the virus? How can mission contribute to the struggle to stop the pandemic? What other forms of ill health call for particular attention from practitioners of Christian mission? Does the church welcome or repel people that are HIV positive?

Can the NHKA justify their intent with these, and similar, projects? The accepted justification for the church's missional inclination is established on one main foundational interpretation of scripture. The missio Dei, as understood by 
David Bosch (1980:240) 'has its origin in the fatherly heart of God. ' He is the fountain of sending love. 'This is the deepest source of mission. It is impossible to penetrate deeper still; there is mission because God loves people' (Bosch

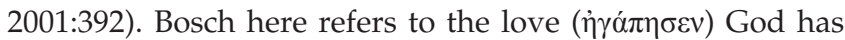
for the world, and his mercy ( $\left.\varepsilon \lambda \varepsilon_{0} \varsigma\right)$, which manifested itself through Christ and is understood as the Trinitarian action (see Volf 2006:3-12) as the basis for mission (see 1 Jn 4:9; Rm 8:32; Jn 3:16). 'Jesus says that the Father has sent him, often adding that it is for the sake of the salvation of the world' (Bosch 1980:240). This is said in the light of the Old Testament, where the church has its roots for inclusivity and universality, particularly in the vision of the prophets. 'God's electing grace calls into being a people charged with the responsibility of being bearers of his universal salvation. He commits himself to them. But they can never claim exclusive claims on him', as shown by Newbigin (1989:85). This God then sends his Son to the world through an act of love for the elected nation(s). Later, this reconciliation is seen in the cross as symbol of reconciliation, and with this 'Trinitarian understanding of mission, but in such a way that it has a Christological concentration because it is precisely Christology that accentuates God's entrance (His mission) into the world' (Bosch 1980:241). Bosch understands this example of God's love to the world as:

$[T]$ he new dimension of God's concern for the world. What is more, it is God's final and definitive concern. Since Christ came we can no longer expect a salvation other than which he inaugurated ... Jesus as missionary is, at the same time, the model for our mission (the Incarnation) and its foundation. (p. 241)

The issue here is the presumed responsibility of the church.

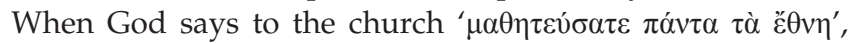
Thomas (1995:103-104) argues: 'He is not giving the Church a commission that is added to their duties; but a commission that belongs to its royal charter (covenant) to be the Church.' Bosch (2001:392) builds on the Dutch theologian Johannes Hoekendijk's understanding of missio Dei, namely that God needs no help 'articulating Himself'; but that the church's missionary efforts only get in the way. 'If anything, the Church simply points to what God is doing in [the] world; and that is all' (Bosch 2001:392).

Mission Dei's locus in the history of theology is the dialectical theology of Karl Barth ${ }^{13}$ with its radical emphasis on the actio $D e i$, which precedes human action and severs missions from any contemporary secular rationale by characterising missions as participation in the redemptive work of God (see Schwarz 1994:591-601). ${ }^{14}$ 'Thus, missions are fundamentally removed from the sphere of purely human activity, characterised and understood as God's will and act, an inalienable indication of God's revelation' (Hartenstein 1939:6). Schwarz (1994:593) understands the mission of the church to 'find the ground of its existence and its limits in God's mission.' Again,

13. Mission for Barth, 'began with the Divine sending of God's self in the Holy Trinity. The church can be in mission authentically only in obedience to God as missio (Thomas 1995:104).

14.See Schwarz (1994:593) for examples of how Hartenstein later moved away from Karl Barth's theology. when we discern about the will of God, we can relate to the action God took by sending Jesus to the world (according to Jn 3:16). Bosch builds on Barth's dialectical theology and Hartenstein's missio Dei, after the Willingen meeting of the International Missionary Council (IMC) in Germany. Bosch (2001) summarises Willingen's message as follows:

The classical doctrine of the missio Dei as God the Father sending the Son, and God the Father and the Son, sending the Holy Spirit was expanded to include yet another 'movement': Father, Son, and Holy Spirit sending the church into the world ... Willingen's image of mission was mission as participating in the sending of God. Our mission has no life of its own: only in the hands of the sending God can it truly be called mission, not least missionary initiative comes from God alone. (p. 390)

The NHKA's missional character should have a specific focus 'on the working of the Trinity in terms of the unity in diversity of the Trinity' that 'will be a key for a theology of religious and cultural pluralism that is the mark of postmodern thought and civilization' (Bevans \& Schroeder 2004:293). But:

[Mission] cannot be something the community possesses, for it is not the community in isolation. It is the living fellowship in which the divine retains the initiative and the community lives in response. (Flett 2010:291)

The participation in God's mission (the missio Dei understood as Trinitarian action and the examples of Jesus' life) reflects on the outcomes that form an essential argument for why we are supposed to be missional. How ${ }^{15}$ should the church do mission? What intent should the church embody when going 'out into the world'?

This concern with current mission is that it goes out to 'serve' (read: impose upon) a specific purpose; regardless of whether it is a church or an organisation. Bevans and Schroeder (2004:284) argue that:

[W] can no longer conceive of mission in terms of church expansion or the salvation of souls; no longer can we conceive of mission as supporting the outreach of colonial powers; no longer can we understand missionary activity as providing the blessings of Western civilization to 'underdeveloped' or 'developing' peoples and cultures; no longer can we conceive of mission as originating from a Christianized North and moving toward a non-Christian, or religiously under-developed South. Mission today, rather, is something much more modest, and at the same time much more exciting - and, indeed, much more urgent. It is much more modest because we realize that the mission is not our, but God's'; ${ }^{16}$ it is much more exciting because

15.Bevans and Schroeder (2004:284-285) explain how 'Mission is about preaching, serving and witnessing to the work of God in our world; it is about living and working as partners with God in the patient yet unwearied work of inviting and persuading women and men to enter into relationship with their world, with one another and with God self. Mission is dialogue. It takes people where they are; it is open to their traditions and culture and experience; it recognizes the validity of their own religious existence and the integrity of their own religious ends. But it is prophetic dialogue because it calls people beyond; it calls people to conversion; is prophetic dialogue because it calls people beyond; it calls people to conversion; it calls people to deeper and fuller truth that can only be found in communion with dialogue's Trinitarian ground. Mission today will be done in what David Bosch calls "bold humility", modelled after mission in Christ's way of humility and self-
emptying and bold proclamation of God's "already" and "not yet" reign.'

16.Newbigin (1964:78) quotes the final statement of the International Missionary Conference's Ghana Assembly of 1957 to 1958: 'The Christian world mission is Christ's, not ours' as cited by Thomas (1995:114). 
it is about God's gracious invitation to humanity to share in the dynamic communion that is at the same time God's selfgiving missionary life; it is more urgent because in a world of globalized poverty, religious violence and new appreciation of local culture and subaltern traditions, the vision and praxis of Jesus of Nazareth can bring new healing and light. (Bevans \& Schroeder 2004:284-285)

A missional inquest for the church is articulated then in terms of the paradigm shift in interpretation, simply as participant in God's mission, with God, not for the church's ${ }^{17}$ survival. Flett (2010:297) explains that the proper posture of the Christian community is as a supplicant, listening to her Lord, and praying for the Spirit.' When this radical (read 'essential') intent is embraced a new contextual paradigm opens up. The church then participates as part of its immediate community a community that does not consist only of members.

\section{The secular age}

Attention to Divinity, in the 3rd millennium, becomes a challenge when the contemporary secular ${ }^{18}$ world does not leave much room for the sacred; the profane becomes the accepted norm, and in some communities 'the possibility of exclusive humanism as a viable social imaginary - a way of constructing meaning and significance without any reference to the divine or transcendence' (Smith 2014:24-26). Vice versa; taking the religious serious in the 3 rd millennium is a challenge when the discriminating practices of the faithful do not leave much space for the outsiders, and the exclusive acceptance of only the 'saved' becomes the norm. Outsiders, ${ }^{19}$ like the 'Markan Jesus himself being treated as an outsider (see Mk 2:6, 18; 3:2, 6, 21-22; 5:17; 6:1-3; 7:5; 12:1)' (Van Eck 2013:8), by the oppressive rule of the Romans and the Temple elite. Institutionalised churches make outsiders and repel those who do not conform to their rule. Is this true of the church today? When the church (any of its congregations) approaches its immediate community (its surrounding neighbourhood), it requires a fundamental intent of inclusive and invitational participation. The church should thus embrace, support, encourage and mediate diversity in its attitude towards any other. James Smith (2014), in his How (not) to be secular, directs the study to a more contemporaneous reality for the church. He asks:

So what does it look like to bear witness in a secular age? What does it look like to be faithful? To what extent have Christians unwittingly absorbed the tendencies of this world? On the one hand, this raises the question of how to reach exclusive

17.Also see Flett (2010:287) explaining that 'mission is a contingent enterprise' if it occurs for a 'perceived need prompted by diminishing membership numbers.'

18.This study draws from Charles Taylor's understandings of 'secular' in Smith (2014:20): (1) A more 'classical' definition of the secular, as distinguished from the sacred - the earthly plane of domestic life. Priests tend the sacred; butchers, bakers, and candlestick makers carry out 'secular' work; (2) a more 'modern' definition of the secular as a-religious - neutral, unbiased, 'objective' - as in a 'secular' public square; (3) Taylor's notion of the secular as an age of contested belief, where religious belief is no longer axiomatic. It's possible to imagine not believing in God. A world view or social imaginary that is able to account for meaning and significance without any appeal to the divine or transcendence.

19.Van Eck (2013:6 of 13) identifies the out-group in Mark's Gospel as the 'sinners' (á $\alpha \rho \tau \omega \lambda$ ol; Mk 2:15), not holy or whole as God is holy or whole, and therefore banned from God's presence in the temple. Also excluded from God's presence and the temple were non-Israelites (outsiders per se) like the Gerasene demoniac (Mk 5:1-13) and the Syrophoenician woman (Mk 7:26). humanists. On the other hand, the question bounces back on the church: To what extent do we 'believe' like exclusive humanists? (p. viii)

Smith argues for the relevance of being faithful in a secular age. It 'matters especially for those believers who are trying to not only remain faithful in a secular age but also bear witness to the divine for a secular age' (Smith 2014:x). Smith exclaims Charles Taylor's plea to be concerned with the 'conditions of belief - a shift in the plausibility conditions that make something believable or unbelievable' (Smith 2014:19). Smith (2014:viii) shows how Charles Taylor points to the reality that your neighbours inhabit an immanent frame; 'they are no longer bothered by the God question' as a problem because they are devotees of exclusive humanism - a way of beingin-the-world that offers significance without transcendence.'

Now in this regard, there has been a titanic change in our western civilization. We have changed not just from a condition where most people lived 'naively' in a construal (part Christian, part related to 'spirits' of pagan origin) as simple reality, to one in which almost no one is capable of this, but all see their option as one among many. (Taylor 2007:12)

This Western view of secularisation bears similarities to the South African context, especially urbanised communities. Regardless of place, what this study argues for is the active participation of the faithful in the secular world amidst all labelled as outsiders. The church can no longer assume that its cultural heritage must be acceptable to everyone in its community. South Africa develops at a rapid pace, and communities and regions diversify. Instead, the church should approach its community with a significant intent that envelopes Jesus' commandments and should resonate with every community. A possible intent could be in a proposal by Crossan (2007):

My proposal is that justice and love are dialectic - like two sides of a coin that can be distinguished but not separated. We think of ourselves as composed of body and soul, or flesh and spirit. When they are separated, we have a physical corpse. Similarly with distributive justice and communal love. Justice is the body of love; love is the soul of justice. Justice is the flesh of love; love is the spirit of justice. When they are separated, we have a moral corpse. Justice without love is brutality. Love without justice is banality. (p. 190)

The institutional church, and Christianity as a body, has arrived at this intersection and needs to take a decisive turn. The globalising effects on reason, through scientific and historical research, are not questioning whether the church, or Christianity, is authoritative, but question which 'default assumptions' (Smith 2014:19) portrayed by contemporary Christianity are believable? ${ }^{20}$ What does it look like to bear

20.The question is 'why would people adapt to a religious alternative', or in other words 'what does faith (religion) bring to globalization?' '(a) Faith brings a mentality of care and compassion, and a belief that it is our duty and obligation to help those less fortunate than us; (b) It asks the question: What is the purpose of life? The answer is that there is more than the material world, regarding strive for capitalistic lifestyle; (c) Faith, has the idea of giving, you are defined by what you give not what you get; (d) Faith brings a dimension of action. Because of its vast infrastructure namely a support mechanism; (e) Faith brings a strong sense of values that can then take the random process of globalization and shape it, so that its injustices can be remedied and its opportunities can be more fairly distributed' (Blair 2009). 
witness in a secular age? What characteristics of the NHKA make people deter from believing the church to be relevant today in South Africa?

\section{Encouragement to participate}

Thomas (1995:viii-xii) identifies historical paradigms ${ }^{21}$ wherein mission acted as the liberating service of the reign of God, as the church-with-others, as mediating salvation, as quest for justice, as evangelism, as contextualisation, as ministry by the whole people of God, as interfaith witness and as action in hope.

The 1st-century followers of Jesus have resisted imperialism and colonisation by living insurgent lives encouraged by Jesus' example of participative action. At the heart of these conflicts was the question of power and its theological justification. Was divine power at the top, with various empires ${ }^{22}$ (taking into account that the Roman Empire is represented by client kings such as Herod, Pontius Pilate and the Judean high priests serving the kingdom of the Temple and appointed by Roman governors)? Or was divine power at work among the marginal and exploited people - where the 1st-century Jesus movement kept escalating? These followers of Jesus lived in a hybrid environment divided between their personal faith and the forced enculturation of the kingdom of Rome's clients. Bevans and Schroeder (2004:11) show that this 'first aspect of the apostolic faith is clearly evident' and 'especially clear in Pauline literature (e.g. Gl 2:15-20; 1 Cor 1:23-24; Rm 5:15-19; 2 Cor 5:19-21; Eph 1:7-10)'. That was the reality then, yet today the similar contemporary realities challenge both the religious and the secular communities.

There is, however, a significant development of the term

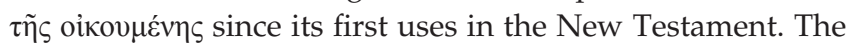
New Testament scriptures 'find the preeminent meaning

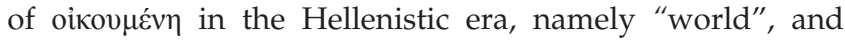
“empire"” (Oborji 2006:154).

The first disciples were dragged before the courts and accused of inciting the whole oikoumene to revolt. In these passages oikoumene indicates the Roman Empire and its structures, but this concept had a very negative connotation. This becomes clear particularly in the account of the temptation, where Satan shows Jesus all the kingdoms of the world ( $L k$ 4:5), and in the book of Revelation where oikoumene indicates Satan's dominion over the whole world (Rv 12:9; 16:14). (Oborji 2006:154)

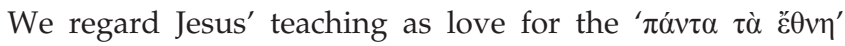
(Mt 24:14; 28:19), for human beings, and the day when God will 'judge the world' (oikoumenē) in righteousness (Ac 17:31), but it was not always interpreted as such because of the negative connotations to it. But Jesus changed that perception. He instigated a culture of approaching any person, including

21.Bevans and Schroeder (2004:286-395) refer to 'constants in context', or 'models' rather than paradigms serving 'as a kind of framework by which the church identifies itself and around which the gospel message takes shape' (Bevans \& Schroeder 2004:72).

22.See Van Eck (2013:2-6 of 13) for the description of the three kingdoms present in the Gospel of Mark; namely the kingdom of Rome, the kingdom of the Temple, and the kingdom of God. outsiders. This encourages inclusive participation - an alternative kingdom that has God on the throne and not the oppressive Caesar, or the corrupt Temple elite. McKnight (2014:74) challenges the evangelical consensus that the kingdom of God' refers to God's redemptive rule and not his people. 'The kingdom of which Jesus speaks is a people governed by a king' (McKnight 2014:74). Why does this matter? Because, whenever we reduce 'kingdom' to God's rule as either justice in the world or God's rule as personal salvation for the human heart, we ignore the close connection between the kingdom of the King's people. 'You can't be kingdom people without being church people' McKnight (2014:79) argues. He (2014) continues:

[I] $\mathrm{t}$ is reasonable to say that the kingdom is the church, and the church is the kingdom - that they are the same even if they are not identical. They are the same in that it is the same people under the same King Jesus even if each term - kingdom, church - gives off slightly different suggestions. (p. 206; emphasis in the original)

In New Testament terminology oikoumene is an ambivalent and context specific concept. This is why Hebrews 2:5 speaks of the oikoumene or world to come in subjection to Jesus Christ and compares this with the oikoumene that passes, that is, with this world (Oborji 2006:154). Jesus as patron redefines the parameters of oikoumene and invites people to become part as insiders of the kingdom of God and 'endowing those who are loyal to his kingdom with the overarching quality of kinship' (Van Eck 2013).

Moreover, the gospel of this kingdom proclaims and enacts God's justice vis-à-vis the injustices of the gospels and kingdoms of Rome and the Temple elite. This becomes clear in the patronage the Markan Jesus endows without distinction to outsiders in Mark's narrative world. Different from Augustus, Antipas, the Herodians and Temple elite, the patronage of Jesus does not have ulterior (political) motives (see Mk 8:29-33), and his mission is not aimed at protecting self-interest through violence; rather his patronage enacts justice and peace. (p. 8)

No longer should those discouraged through institutional and cultural-religious, and oppressive practices, experience marginalisation. Jesus resolves that assumption through his example as patron, and welcoming anyone to participate.

Those who have $\pi$ í $\tau \iota \varsigma$ [loyalty] are taken up in the mission and kingdom of the patron (see Mk 2:5; 4:40; 5:34; 10:52; 11:22, 24;

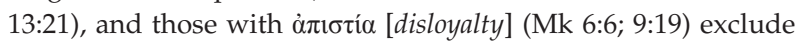
themselves from the kingdom. (Van Eck 2013:11 of 13)

Followers of Jesus can no more aspire to be patrons of the kingdom of God to outsiders if they themselves embody exclusivist and oppressive inadequacies of the kingdom of Rome, or the kingdom of the Temple. This new identity entails the willingness to be taken up in the mission of its patron by standing up for justice and showing compassion in the same way as the patron of the kingdom of God (Van Eck 2013:11 of 13).

To the same degree that the kingdom has been inaugurated in Jesus, the kingdom can be realized among us. To the degree that the kingdom has not yet been realized, it cannot be lived out in the present. (McKnight 2014:39) 
Understanding this truth gives us a sense of hope, and realism, as we grow in Christlikeness. Kingdom mission also requires context. Likewise, faithfulness in the kingdom mission means we must 'embed kingdom realities' in our own context, to intentionally counter rule kingdoms in our world.

Only when accepting the mission Dei as God's mission, and not the mission of the church, can the church be taken up in God's mission. The church can contribute in the mission of God through such a missional character.

Let us encourage the participatio Jesu, in a believable way so that the Christian 'mission, identity and ethics, pax [peace], concordia [social harmony], felicitas [happiness], clementia [mercy], iustitia [justice], salus [health], virtus [the common good] and spes [hope]' (Van Eck 2013:12 of 13) can be available to all. And it should be available to all, even to the church. In Mark 8:34 a clear outline is given for anyone who wants to participate in the kingdom of God:

And when he had called the people unto him with his disciples also, he said unto them, Whosoever will come after me, let him deny himself, and take up his cross, and follow me.

When this participatio happens, the focus shifts from the immediate secular community as missional conquest of the church to the church as participating in the kingdom of God; as alternative kingdom to that of the other globalised kingdoms. The church is not the kingdom of God. The church, as an institution, falls under the guidance of the Markan explanation of participation in the kingdom (Mk 8:34). The church's mission is to 'mediate the presence of God in this world' (McKnight 2014:123) by embracing its identity as an alternative kingdom. Local churches must embody the vision of Jesus in a way that tells his kingdom story. 'Kingdom mission forms a kingdom people - and that kingdom people in the present world is the church' (McKnight 2014:123).

This is the intent derived from the missional inquest proposed to the NHKA. This shift of intent vitalises the church's ability to embrace community, not to envelop it as an institution.

For the church to attempt this paradigm shift it has to, at least, investigate creative ways of approaching its immediate community. Friedman (2007:607), regarding the people who dared to imagine the fall of the Berlin wall, and were 'courageous enough to act upon that imagination', explains the potential that globalisation has made accessible to everyone. Even to the church. 'Therefore, thinking about how we stimulate positive imaginations is of the utmost importance' (Friedman 2007:608).

As Irving Wladawsky-Berger, the IBM computer scientist, put it to me: We need to think more seriously than ever about how we encourage people to focus on productive outcomes that advance and unite civilization - peaceful imaginations that seek to 'minimize alienation and celebrate interdependence rather than self-sufficiency, inclusion rather than exclusion,' openness, opportunity, and hope rather than limits, suspicion, and grievance. (Friedman 2007:609)
No longer can the church support any form of mission or project that repels or deters communities from participating as a consequence of church-centred intent.

\section{Concluding remarks}

Globalisation can threaten Christianity with a complex diversity of kingdoms. These kingdoms are embedded in the authorities, principles and systems of the world, and in different ways in our immediate community. Our immediate communities, whether religious or secular, are being oppressed and subjugated to these kingdoms and labelled as outsiders, always struggling to be accepted, to express their distinctiveness, and share kinship as members of oikoumene. Our missional character can no longer be comparable to the kingdoms of a globalising world that develops without an accountable, responsible tolerance, distributive justice, and without intent of equitable pax Humanitas.

Questions the church can consider, when approaching its immediate community and understanding missional action as a paradigm shift to become a participant, not the organiser (see Flett 2010:298):

- What language $\mathrm{e}^{23}$ is used by the NHKA to participate with the un-churched, and post-church communities, in the community?

- If evangelisation is understood to identify and win inactive members back to church, what does it imply about the church's missional character?

- If the church does not responsibly take part in its local globalising communities, for what reason would the next generation laud the church with the authority as dependable forum in local oikoumene?

- What is a believable character of Christian mission towards our churches' current (secular and non-religious) communities? Especially to the communities that regard the church as redundant.

- How can the church creatively articulate the kingdom of God in its local community, where locality is perceived as the open 'pizza dough' of Friedman?

- Who will miss a church project when it is discontinued? The church members or its immediate community?

- How does the churches' missional character look when the church is a 'community of reconciliation moving out in solidarity with the world in the active knowledge that God died for it, too'?

This article locates Christian mission, with the intent to serve through participation in oikoumene, and not to rule, as a supposedly sustainable foundation for humanity. A missional character that encourages the church ${ }^{24}$ to participate in the kingdom of God, with no secondary gains, shifts intent

23.See Schreiter's (2007:113) Constructing local theologies, in which he argues that tradition is important for human community in that it provides 'identity, a communication system with cohesion and continuality, and resources for dealing communication system with cohesion and continuality, and resources for dealing with innovation ... that becomes the matrix within which a theory of tradition can
be developed.'

24.Van der Merwe (2011:9 of 9) shows that there is unification about the 'definition' of missional action that needs to be taken in the NHKA, but that the schism of missional action that needs to be taken in the NHKA, but that the schism
between the 'empirical' (literal church in context) and the 'defined' (the ideal church) subject, still needs to be bridged (see also Nel 1994:12) 
to embodying characteristics of love entwined with justice. Imaginative creativity dwells in these characteristics of love and can reveal believable action of the church in oikoumene today.

\section{Acknowledgements Competing interests}

The authors declare that they have no financial or personal relationships which may have inappropriately influenced them in writing this article.

\section{Authors' contributions}

This article represents a reworked version of aspects from the PhD dissertation of P.J.J. (University of Pretoria) with E.v.E. (University of Pretoria) as supervisor.

\section{References}

Barth, K., 1961, Kirchlicke Dogmatik II/2, T\&T Clark, Edinburgh.

Bevans, S.B., 2002, Models of contextual theology, Orbis Books, Maryknoll, NY

Bevans, S.B. \& Schroeder, R.P, 2004, 'Constants in context: A theology for mission today', in American Society of Missiology Series, vol. 30, Orbis Books, Maryknoll, NY.

Beyers, J., 2013, 'Die roeping van die kerk', HTS Teologiese Studies/Theological Studies 69(1), Art. \#1945, 10 pages. http://dx.doi.org/10.4102/hts.v69i1.1945

Blair, T., 2009, 'Faith and globalization', in Blair Foundation Lectures, voice recording, Tony Faith Foundation, viewed 15 May 2015, from http://tonyblairfaithfoundation. org/projects/supporting-leaders/supporting-leaders-teaching-resources

Bosch, D.J., 1980, Witness to the world: The Christian mission in theological perspective, John Knox Press, Atlanta, GA.

Bosch, D.J., 1983, 'The structure of mission: An exposition of Matthew 28:16-20', in W.R. Shenk (ed.), Exploring church growth, pp. 218-248, William B. Eerdmans, Grand Rapids, MI.

Bosch, D.J., 2001, Transforming mission: Paradigm shifts in theology of mission, Orbis Books, New York, NY.

Crossan, J.D., 2007, God \& empire: Jesus against Rome, then and now, Harper, San Francisco, CA.

Flett, J.G., 2010, The witness of God: Trinity, mission Dei, Karl Barth, and the nature of Christian community, Eerdmans Publishing Co., Grand Rapids, MI.

Friedman, T.L., 2007, The world is flat: A brief history of the twenty-first century, Picador/Farrar, Straus \& Giroux, New York, NY.

The Global Ethic Foundation, Die Prinzipien eines Weltethos, viewed 15 May 2015 from http://www.weltethos.org/basisdokumente/

Hartenstein, K., 1939, 'Die trinitarische Verkündigung in der Welt der Religionen', in K. Hartenstein (ed.), Die Deutsche evangelische Heidenmission (Jahrbuch), pp. 21-34, Selbstverslag die Missions Konferenz, Hamburg.

Held, D. \& McGrew, A. (eds.), 2000, The global transformations reader: An introduction to the globalization debate, Polity Press, Cambridge.

Hellyer, P., 1999, Stop: Think, Chimo Media, Toronto.

Hooykaas, R.J., 1974, Religion and the rise of modern science, Clarendon Press, London.

Kalu, O.U., Vethanayagamony, P. \& Chia, E.K. (eds.), 2010, Mission after Christendom: Emergent themes in contemporary mission, John Knox Press, Louisville, KY.

Litonjua, M.D., 1999, 'Global capitalism', Theology Today 56, 210-228. http://dx.doi. org/10.1177/004057369905600207

Lovelock, S., 1987, Gaia: A new look at life on earth, Oxford University Press, New York, NY.

McKnight, S., 2014, Kingdom conspiracy: Returning to the radical mission of the local church, Brazos Press, Grand Rapids, MI.

Millennial Impact Report, 2014, 'How Millennials connect, give and get involved with the issues that matter to them', in U.S. Chamber for Commerce Foundation viewed 15 May 2015, from http://www.uschamberfoundation.org/millennialgeneration-research-review
Moltmann, J., 2001, 'The destruction and healing of earth', in in M. Stackhouse (ed.), God and globalisation: The spirit and the modern authorities, vol. 2, pp. 166-190, God and globalisation: The spirit and
Trinity Press International, Harrisburg.

Nederduitsch Hervormde Kerk van Afrika (NHKA), 2007, 'Riglyne vir die apostolaat in die NHKA', in Agenda vir die 68ste Algemene Kerkvergadering van die Nederduitsch Hervormde Kerk van Afrika, bl. 60-65, NHKA, Pretoria.

Nederduitsch Hervormde Kerk van Afrika (NHKA), 2010, 'Verslag van die Raad vir Apostolaat', in Agenda vir die 69ste Algemene Kerkvergadering van die Nederduitsch Hervormde Kerk van Afrika, bl. 228-237, NHKA, Pretoria.

Nel, M., 1994, Gemeentebou, Orion Uitgewers, Halfway House.

Newbigin, L., 1964, Trinitarian faith and today's mission, John Knox Press, Richmond, VA.

Newbigin, L., 1989, The gospel in a pluralistic society, Wm. B. Eerdmans, Grand Rapids, MI.

Niemandt, C.J.P., 2012, 'Trends in missional ecclesiology', HTS Teologiese Studies/ Theological Studies 68(1), 1-9. http://dx.doi.org/10.4102/hts.v68i1.1198

Oborji, F.A., 2006, Concepts of mission: The evolution of contemporary missiology, Orbis Books, Maryknoll, NY.

Pears, A., 2010, Doing contextual theology, Routledge, New York, NY.

Reader, J., 2008, Reconstructing practical theology: The impact of globalization, Ashgate Publishing Company, Burlington, NJ.

Robertson, R., 1992, Globalization: Social theory and global culture, Sage, London.

Robertson, R., 2000, 'Globalization and the future of "traditional religion"', in M. Stackhouse (ed.), God and globalization: Religion and the powers of the common life, vol. 1, pp. 53-68, Trinity Press International, Harrisburg, PA.

Schreiter, R.J, 2007, Constructing local theologies, Orbis Books, Maryknoll, NY.

Schwarz, G., 1994, 'Karl Hartenstein, 1894-1952, Mission with a focus on itself' in G. Anderson, R.T. Coote, N.A. Horner \& J.M. Phillips (eds.), Mission legacies: Biographical studies of leaders of the modern missionary movement, pp. 591-601, Orbis Books, Maryknoll, NY.

Smith, J.K.A., 2014, How (not) to be secular: Reading Charles Taylor, Eerdmans Publishing Company, New York, NY.

Stackhouse, M.L., 2000, 'General introduction', in M. Stackhouse (ed.), God and globalisation: Religion and the powers of the common Life, vol. 1, pp. 1-52, Trinity Press International, Harrisburg, PA

Stackhouse, M.L., 2001, 'General introduction', in M. Stackhouse (ed.), God and globalisation: The spirit and the modern authorities, vol. 2, pp. 1-52, Trinity Press International, Harrisburg, PA.

Stiegler, B., 2010, 'Institute for Research and Innovation', video recording, Centre Georges Pompidou, viewed 15 May 2015, from http://www.labkultur.tv/en/video/ bernard-stiegler-culture-heart-new-economical-and-industrial-development

Taylor, C., 2007, A secular age, Harvard University Press, Cambridge.

Thomas, N.E. (ed.), 1995, Classic texts in mission and world Christianity, Orbis Books, Maryknoll, NY. (American Society of Missiology ser. 20).

Turner, B.S., 2011, Religion and modern society: Citizenship, secularization, and the state, Cambridge University Press, Cambridge. http://dx.doi.org/10.1017/ CBO9780511975660

Ungerer, A., 2013, 'Hoe lyk die kerk in ons wêreld?', Die Hervormer 106(2), 2

Van Eck, E., 2013, 'Mission, identity and ethics in Mark: Jesus, the patron for outsiders', HTS Teologiese Studies/Theological Studies 69(1), Art. \#2003, 13 pages. http:// HTS Teologiese Studies/Theological
$\mathrm{dx}$.doi.org/10.4102/hts.v69i1.2003

Van der Merwe, J.C., 2011, 'Missionale gemeentes in die Nederduitsch Hervormde Kerk van Afrika - Teologies verantwoord', HTS Teologiese Studies/Theological Studies 67(3), Art. \#1094, 9 pages. http://dx.doi.org/10.4102/hts.v67i3.1094

Van Wyk, D.J.C. jr., 2013, 'Maak die beste gebruik van elke geleentheid', Die Hervormer 105(10), Januarie, 1.

Van Wyk, I.W.C., 2013, 'Die Hervormde Kerk: Soekend na 'n weg tussen ekklesiologiese verstarring en innovasie sonder tradisie', HTS Teologiese Studies/ Theological Studies 69(1), Art. \#1999, 11 pages. http://dx.doi.org/10.4102/hts. v69i1.1999

Van Wyk, W., 2013, 'Kerkrade praat oor kerkwees in die huidige tyd', e-Hervormer 6(14), besigtig 15 Mei 2015, by http://hervormer.co.za/images/e-Hervormer_16_05_13. pdf

Volf, M., 2006, 'Being as God is: Trinity and generosity', in M. Volf \& M. Welker (eds.), God's life in trinity, pp. 3-12, Fortress Press, Minneapolis, MN.

Volf, M., 2008, 'Themes in faith and Globalization', viewed 20 April 2014, from http:// www.coursehero.org/lecture/themes-faith-and-globalization

Yale University lectures, 'Themes in faith and globalization', viewed 15 May 2015 from http://www.coursehero.org/course/faith-and-globalization 